\title{
MOLEKULÁRIS DESZKRIPTOROK ALKALMAZÁSA OKTÁN IZOMEREK TOPOLÓGIAI SZERKEZETÉNEK JELLEMZÉSÉRE
}

\section{APPLICATION OF MOLECULAR DESCRIPTORS IN THE TOPOLOGICAL CHARACTERIZATION OF OCTANE ISOMERS}

\author{
Réti Tamás ${ }^{1}$, Varga Péter $^{2}$, Réger Mihály ${ }^{3}$ \\ Óbudai Egyetem, Bánki Donát Gépész és Biztonságtechnikai Mérnöki Kar, \\ Anyag- és Gyártástudományi Intézet 1081 Budapest, Népszínház utca 8. Telefon: \\ $+36-1-666-5386$ \\ ${ }^{1}$ reti.tamas@bgk.uni-obuda.hu
}

\begin{abstract}
The finite set of octane isomers is generally used for evaluating and comparing the discriminating performance of various topological descriptors (graph invariants). In this project 9 different graph irregularity indices are investigated, all of them belong to the family of degree-based topological invariants. Using a comparative test on the set of 18 octane isomers, the main results are presented and discussed. By means of regression analysis, we studied the intercorrelations between the irregularity indices and some physicochemical properties. The degree of the intercorrelation was evaluated by correlation coefficients. It has been concluded, that among 9 topological descriptors there are several irregularity indices by which the preselected physicochemical properties of octane isomers can be predicted with a satisfactory accuracy.
\end{abstract}

Keywords: structural chemistry, graph invariants, statistical analysis

\section{Összefoglalás}

Az oktán izomerek elterjedten használatosak a különféle típusú topológiai deszkriptorok (gráfinvariánsok) diszkriminációs képességének minősítésére és összehasonlítására. Jelen projekt keretében 9 különböző irregularitási indexet vizsgáltunk, ezek a gráfok fokszámai alapján definiált topológiai invariánsok. A 18 oktán izomerrel végzett összehasonlító teszt főbb eredményeit ismertetjük és értékeljük. Regresszió-analízis alkalmazásával elemeztük az irregularitási indexek és egyes fizikaikémia anyagjellemzők közötti interkorrelációt. Az interkorreláció mértékének számszerủ jellemzésére a korrelációs együtthatók szolgáltak. Arra következtettünk, hogy a vizsgált irregularitási indexek között több olyan van, amellyel az oktán izomerek egyes fizikai-kémiai tulajdonsága kielégítő pontossággal elöre becsülhető.

Kulcsszavak: szerkezeti kémia, gráf invariánsok, statisztikai analízis

\section{Bevezetés}

A szerkezeti kémiában általános törekvés a szerves vegyületek szerkezete és ezek fizikai-kémiai tulajdonságai közötti összefüggések kvantitatív kritériumon alapuló leírása. A szerves vegyületek között a legegyszerübb szerkezetüek a szénhidro- 
gének, ennek tulajdonítható, hogy tulajdonságaik predikciójára elterjedten használatosak a gráfelméleten alapuló eljárások $[1,2]$. Ezek közös sajátossága, hogy adott nszámú karbon atomot tartalmazó szénhidrogén-vegyületet egy n csúcspontú gráffal modellezik, a gráf szerkezetének számszerü jellemzésére ún. topológiai invariánsokat (molekuláris topológiai deszkritorokat) használnak. Jelen kutatási projekt keretében azt vizsgáltuk, hogy a topológiai invariánsok egy speciális osztályának tekintett „gráf-irregularitási indexek" milyen hatékonysággal alkalmazhatók a mindössze 8 karbon atomot tartalmazó ún. oktán-izomerek egyes fizikai-kémiai tulajdonságainak becslésére, predikciójára.

\section{Irregularitási indexek származtatása}

Vizsgálatinkat $n$ csúcsszámú és $m$ élszámú összefüggő gráfokra korlátoztuk, ahol $\mathrm{V}$ illetve $\mathrm{E}$ a gráf csúcsainak illetve éleinek halmazát jelöli. A szokásos terminológiát használva, $d_{u}$ a gráf egy tetszőleges u csúcsának fokszáma, és uv pedig a gráfnak két szomszédos, u és $\mathrm{v}$ csúcsait összekötő éle. Definíció szerint egy gráf reguláris, ha minden egyes csúcsának fokszáma azonos, és irreguláris, ha léteznek különböző fokszámú csúcsai.

Gráfok strukturális inhomogenitásának kvantitatív jellemzésére elterjedten használatosak a különféle típusú irregularitási indexek. Egy $G$ gráf $\operatorname{Irr}(\mathrm{G})$ topológiai invariánsát a gráf irregularitási indexének szokás nevezni, ha $\operatorname{Irr}(\mathrm{G}) \geq 0$, és $\operatorname{Irr}(\mathrm{G})=0$ akkor és csak akkor, ha a gráf reguláris [3]. Az oktán izomereknek pontosan 18 különböző változata ismert, következésképpen ezekhez 18 különbözö (nem izomorf) gráf rendelhető. (1. ábra). Ezek mindegyike nem-reguláris gráf.

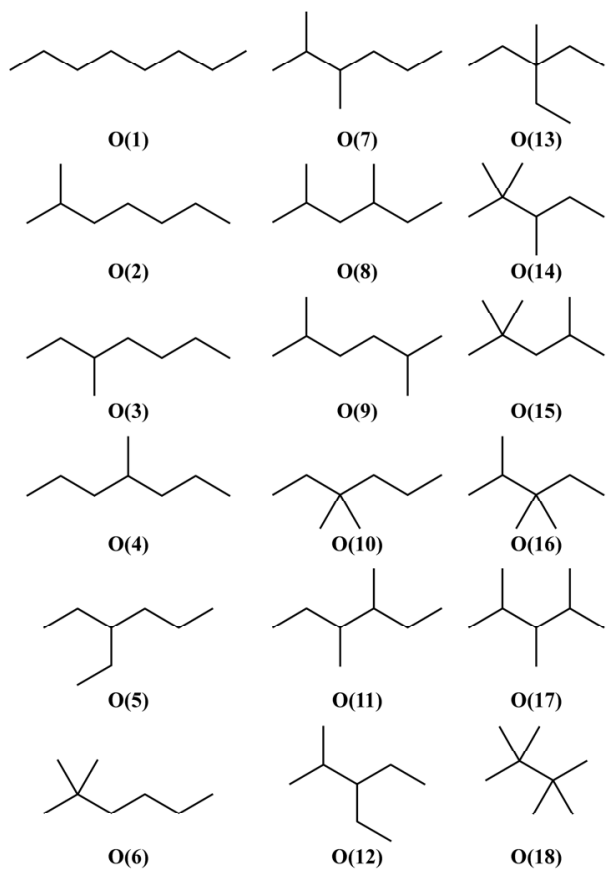

1. ábra. Oktán-izomerek gráfjai

Az oktán izomereket reprezentáló gráfok a fa-gráfok családjába tartoznak, következésképpen $\mathrm{n}=8$ csúcsot és $\mathrm{m}=7$ élet tartalmaznak. E gráfok strukturális jellemzésére, 9 különböző irregularitás indexet választottunk ki, definiálásukra az alábbi képletek szolgáltak:

$$
\begin{aligned}
& \operatorname{IR} 1(G)=\sum_{u \in V} d_{u}^{3}-\frac{2 m}{n} \sum_{u \in V} d_{u}^{2} \\
& \operatorname{IR2}(G)=\sqrt{\frac{\sum_{u v \in E} d_{u} d_{v}}{m}}-\frac{2 m}{n} \\
& \operatorname{IRF}(G)=\sum_{u v \in E}\left(d_{u}-d_{v}\right)^{2} \\
& \operatorname{IRA}(G)=\sum_{u v \in E}\left(d_{u}^{-1 / 2}-d_{v}^{-1 / 2}\right)^{2} \\
& \operatorname{IRB}(G)=\sum_{u v \in E}\left(d_{u}^{1 / 2}-d_{v}^{1 / 2}\right)^{2} \\
& \operatorname{IRC}(G)=\frac{\sum_{u v \in E} \sqrt{d_{u} d_{v}}}{m}-\frac{2 m}{n}
\end{aligned}
$$




$$
\begin{aligned}
& \operatorname{IRDIF}(G)=\sum_{u v \in E}\left|\frac{d_{u}}{d_{v}}-\frac{d_{v}}{d_{u}}\right| \\
& A L(G)=\sum_{u v \in E}\left|d_{u}-d_{v}\right| \\
& \operatorname{IRL}(G)=\ln \prod_{u v \in E}\left\{\frac{\max \left(d_{u}, d_{v}\right)}{\min \left(d_{u}, d_{v}\right)}\right\}
\end{aligned}
$$

\section{Korrelációs vizsgálatok eredményei}

Vizsgálataink alapvetően annak tisztázására irányultak, hogy a fentebb definiált irregularitási indexek milyen hatékonysággal alkalmazhatók az oktán izomerek bizonyos fizikai-kémiai tulajdonságainak predikciójára. Erre a célra a leginkább kézen fekvő módszernek a lineáris, egyváltozós korreláció-analízisen alapuló statisztikai módszer kínálkozott. Kilenc irregularitási index felhasználásával három kiválasztott anyagtulajdonságra vonatkozóan, (nevezetesen a forráspont (Bp), a párolgási standard entalpia (DHVAP) valamint az entrópia (Entrópia)) végeztünk összehasonlító korrelációelemzést. A korrelációs együtthatók (R) előjeles számértékeit az 1.táblázat összesíti. A táblázatban a becsült korrelációs együtthatók közül számszerüen csak azokat tüntettük fel, amelynek abszolút értéke 0,8-nál nagyobbra adódott.

1. táblázat. Korrelációs tényezök (R) számitott értékei

\begin{tabular}{|c|c|c|c|}
\hline Index & Bp & DHVAP & Entrópia \\
\hline IR1 & - & $-0,919$ & $-0,951$ \\
\hline IR2 & - & $-0,818$ & $-0,936$ \\
\hline IRF & - & $-0,938$ & $-0,907$ \\
\hline IRA & $-0,820$ & $-0,958$ & $-0,906$ \\
\hline IRB & $-0,805$ & $-0,953$ & $-0,912$ \\
\hline IRC & - & $-0,881$ & $-0,954$ \\
\hline IRDIF & $-0,830$ & $-0,939$ & $-0,863$ \\
\hline AL & $-0,816$ & $-0,976$ & $-0,897$ \\
\hline IRL & $-0,837$ & $-0,987$ & $-0,898$ \\
\hline
\end{tabular}

\section{Következtetések}

$\mathrm{Az}$ eredményeket értékelve az alábbi következésekre juthatunk:

- Az oktán izomerek forráspontjának (Bp) predikciója lineáris regresszióval származtatott egyenletekkel kevésbé sikeres. A legjobb esetben is a korrelációs együttható értékére csak $\mathrm{R}=-0,837$ adódott, ezt az értéket az IRL irregularitási index felhasználásával lehetett elérni. A szakirodalomban több helyen is utalnak arra, hogy a Bp forráspont elörejelzése tünik a leginkább problematikusnak a vizsgált fizikaikémiai tulajdonságok között.

- Ami a párolgási standard entalpia (DHVAP) predikcióját illeti, mint megállapítható, többféle irregularitási index alkalmazása is kielégítő eredményhez vezet. Ezek között a predikció hatékonyságát tekintve a legjobb az IRL index, amelyre vonatkozóan $R=-0,987$.

- Hasonlóan ígéretes eredményeket kaptunk az Entrópia becslésekor. Ez esetben a legjobb predikciót az IRC index szolgáltatta, ezt a megállapítást egyértelmüen alátámasztja a $\mathrm{R}=-0,954$ korrelációs tényező kimagasló értéke.

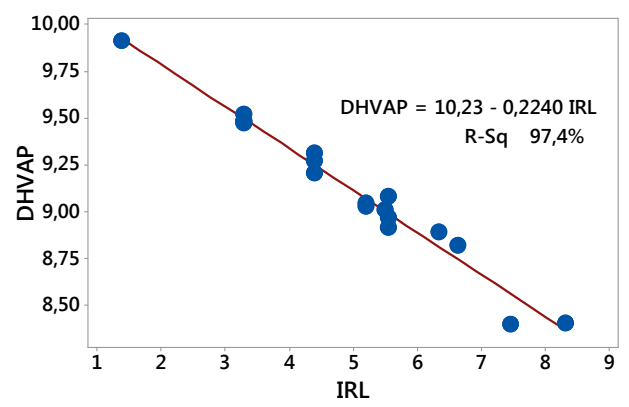

2. ábra. Az IRL irregularitási index és a DHVAP anyagjellemzö közötti összefüggés 


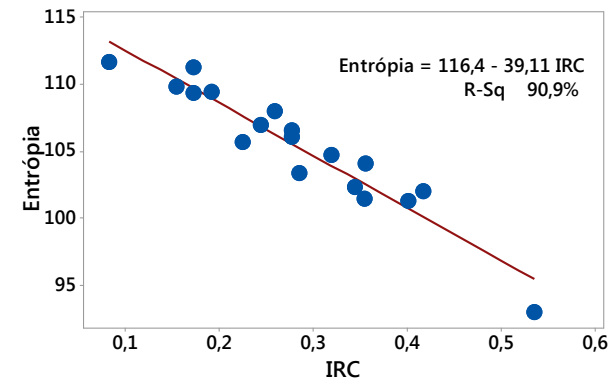

3. ábra. Az IRC irregularitási index és az Entrópia közötti összefüggés
A korrelációs vizsgálatok leginkább relevánsnak tekinthető eredményeit a DHVAP és az Entrópia tulajdonságokra vonatkozóan 2. és 3. ábrák diagramjai szemléltetik.

\section{Szakirodalmi hivatkozások}

[1] R. Todeschini, V. Consonni, Handbook of Molecular Descriptors, 2nd ed., Wiley-VCH, Weinheim, 2009.

[2] I. Gutman, Degree-Based Topological Indices, Croat. Chem. Acta, 86, 2013, 351361.

[3] T. Réti, E. Tóth-Laufer, On the construction and comparison of graph irregularity indices, Kragujevac J. Sci. 39 (2017) 66-88. 